\section{Studi Eksperimental Pengaruh Kecepatan Engkol dan Variasi Diameter Disk terhadap Amplitudo, Frekuensi dan Daya pada Mekanisme Pembangkit Gelombang}

\author{
Miftahul Ulum¹, Ardi Noerpamoengkas², Ahmad Anas Arifin, \\ dan Hanif Darmawan Firmansyah ${ }^{4}$
}

1Institut Teknologi Adhi Tama Surabaya

e-mail: ulum@itats.ac.id
Journal of Mechanical Engineering, Science, and Innovation

e-ISNN: 2776-3536

2021, Vol. 1, No. 1

ejurnal.itats.ac.id/jmesi

\begin{abstract}
The renewable energy in Indonesia still needs to be developed such as energy coming from micro hydro electrical power plant which can minimize the use of fossil as the energy source. Basically, water wave can be used as an energy source having relatively low risk and is easy to renew. This experimental research conducted simulation on the water wave generator by varying the frequency of motor speed and crank distance toward amplitude and wave frequency. The independent variables of this research involved wave height or amplitude and the yielded wavelength. After developing a prototype of wave tank, the researcher measured and comp red some parameters influencing the water wave calculation. They comprised of wave amplitude (A), wave period (T), wavelength $(\lambda)$ and frequency $(f)$, motor pin speed, and crank shaft diameter. As a result, kinds of parameters influencing each other and how the speed and crank shaft variations affected the existing parameters could be noticed. Thus, the biggest frequency by $2.83 \mathrm{~Hz}$ occurred on the crank number 1 with speed $120 \mathrm{rpm}$, whereas the highest amplitude by $30 \mathrm{~mm}$ happened on the crank number 3 with speeds 1 and 2. Meanwhile, the biggest power was obtained on the crank number 3 with speeds 1 and 2 by power wave generated 4.41 watt.
\end{abstract}

Keywords: water wave, micro hydro, wave tank, frequency, amplitude, power generated.

\begin{abstract}
Abstrak
Kebutuhan akan energi yang terbarukan di Indonesia perlu dikembangkan salah satunya adalah energi yang berasal dari pembangkit listrik mikrohidro karena dapat meminimalisir penggunaan sumber energi yang berasal dari fosil. Penggunaan gelombang air sebagai seumber energi juga dirasa memiliki dampak resiko yang relatif kecil, serta pemanfaatannya yang mudah diperbarui. Pada penelitian ini akan dilakukan studi eksperimental dengan simulasi pada alat pembuat gelombang air. Studi eksperimental ini menggunakan metode variasi frekuensi kecepatan motor dan jarak engkol terhadap amplitudo dan frekuensi gelombang. Variabel bebas yang digunakan dalam penelitian ini adalah tinggi gelombang atau amplitudo dan panjang gelombang yang dihasilkan. Dengan membuat prototype wave tank dan melakukan pengukuran dan perbandingan antara parameter-parameter yang berpengaruh terhadap perhitungan gelombang air yaitu amplitude gelombang (A), periode gelombang (T), dan panjang gelombang $(\lambda)$, kecepatan putaran motor dan diameter poros engkol maka didapatkan parameter apa saja parameter yang saling berpengaruh serta bagaimana variasi kecepatan dan variasi poros engkol berpengaruh terhadap parameter-parameter yang ada. Sehingga dari penelitian ini didapatkan Frekuensi terbesar pada crank nomor 1 dengan kecepatan $120 \mathrm{rpm}$ dengan frekuensi sebesar $2.83 \mathrm{~Hz}$, amplitudo terbesar didapatkan pada crank nomor 3 kecepatan 1 dan 2 dengan
\end{abstract}


amplitudo sebesar $30 \mathrm{~mm}$, dan daya terbesar didapatkan pada crank nomor 3 kecepatan 1 dan 2 dengan energi bangkitan 4.41 watt.

Kata kunci: gelombang air, microhidro, wave tank, frekuensi, amplitude, energi bangkitan.

Handling Editor: Ayu Setyaning Sayekti Poesoko

This article was presented at the SENASTITAN 2021, 6 Maret 2021, Surabaya.

\section{PENDAHULUAN}

Kebutuhan akan energi listik di Indonesia semakin meningkat, hal ini dapat di ketahui dengan adanya indeks pembangunan manusia (IPM) terhadap konsumsi kebutuhan energi listrik [1]. Energi listrik yang di hasilkan dari energi fosil dalam kurun waktu tertentu akan kian sedikit, untuk itu diperlukan adanya terobosan baru dengan pemanfaatan energi terbarukan. Energi terbarukan saat ini banyak berkembang antara lain adalah energi yang dihasilkan dari laut [2]. Dalam pemanfaatan energi yang dihasilkan oleh gelombang laut sangat bervariasi, diantaranya adalah dengan menggunakan metode ayunan pendulum [3], Adapun metode lainya dengan prinsip pemanfaatan pelampung baik dengan mekanisme apung maupun mekanisme tetap [4][5]. Gelombang laut sangat berpotensi dalam pengembangan energi terbarukan karena banyak model sistem konversi yang dapat diaplikasikan dalam memanen energi kinetis maupun energi potensial yang ada pada gelombang laut [6].

Pada penelitian sebelumnya telah dilakukan percobaan menggunakan prototipe gelombang laut mikrohidro sistem dalam mendapatkan estimasi tinggi gelombang terhadap voltase, arus, serta efisiensi [7]. Namun dalam percobaan tersebut tidak dijelaskan model mekanisme serta parameter yang digunakan pada eksperimen. Pada penelitian itu juga didapatkan kesimpulan dimana tinggi gelombang juga mempengaruhi tingginya arus, voltase bangkitan serta efisiensi. Pada penelitian ini akan dilakukan eksperimen dengan menggunakan prototipe kolam pembangkit gelombang dengan menggunakan variasi diameter disk dan kecepatan putaran. Mekanisme yang digunakan adalah mekanisme engkol.

\section{METODE DAN ANALISIS Gelombang Laut}

Upaya untuk memanfaatkan energi gelombang laut telah banyak dilakukan baik dengan konsep yang sederhana maupun yang canggih. Sejumlah percobaan telah dilakukan oleh para ahli di bidang gelombang laut dan telah ditemukan beberapa konsep pemanfaatannya. Pada dasarnya sebuah benda yang berada diatas permukaan laut akan selalu memperoleh gaya eksternal yang menyebabkan benda tersebut bergerak. Gerakan ini disebabkan terutama oleh gelombang. Dalam memperoleh gelombang benda mengalami 2 jenis gerak yaitu pertama gerakan rotasi, gerak ini merupakan gerak putaran meliputi: rolling, pitching, yawing. Kedua gerakan Linier, gerak ini merupakan gerak lurus beraturan sesuai dengan sumbunya meliputi: surging, swaying, heaving. Energi gelombang dapat dirumuskan sebai berikut.

Teori paling sederhana adalah teori gelombang Airy, yang juga disebut teori gelombang linier atau teori gelombang amplitudo kecil, yang pertama kali dikemukakan oleh Sir. George Biddell Airy pada tahun 1845. Selain mudah dipahami, teori tersebut sudah dapat digunakan sebagai dasar dalam merencanakan bangunan pantai. 


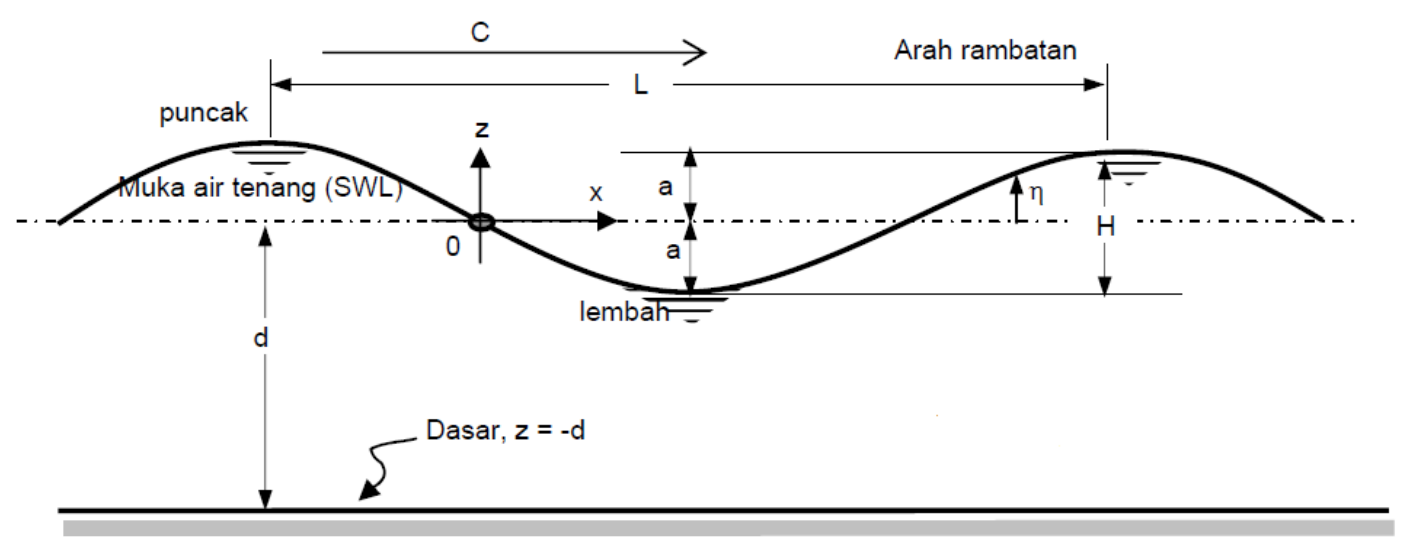

Gambar 1. Sketsa gelombang laut [8]

Gambar 1 diatas menunjukkan suatu gelombang yang berada pada sistem korninat x-z. Gelombang bergerak pada sumbu x dengan ketinggian gelombang $\mathrm{H}(\mathrm{m})$, panjang gelombang L (m), dan SWL atau mean sea water level (muka air tenang). Energi potensial gelombang dapat di tulis dengan persamaan berikut:

$$
E=\frac{1}{2} E=\frac{1}{2} \rho \rho g g_{\mathrm{A}^{2}}
$$

Dimana $E$ adalah energi potensial gelombang (joule), $g$ percepatan gravitasi, $\rho$ densitas air, dan $A$ amplitudo (meter).

Dalam menentukan parameter-parameter pada gelombang laut sangatlah penting untuk diketahui, karena dapat membantu dalam proses pembuatan desain alat konversi energi yang sesuai untuk diaplikasikan. Pada penelitian ini metode yang digunakan adalah metode ekperimen, dimana parameter yang akan diberikan berupa variasi diameter disk pada poros engkol sebesar $8 \mathrm{~cm}, 10 \mathrm{~cm}$, dan $12 \mathrm{~cm}$. Selain itu juga akan diberikan perbandingan kecepatan pada putaran engkol sebesar $100 \mathrm{rpm}$ dan 120 rpm yang bisa diatur pada motor. Hal ini bertujuan untuk mendapatkan nilai amplitude gelombang, frekuensi dan daya yang dihasilkan.

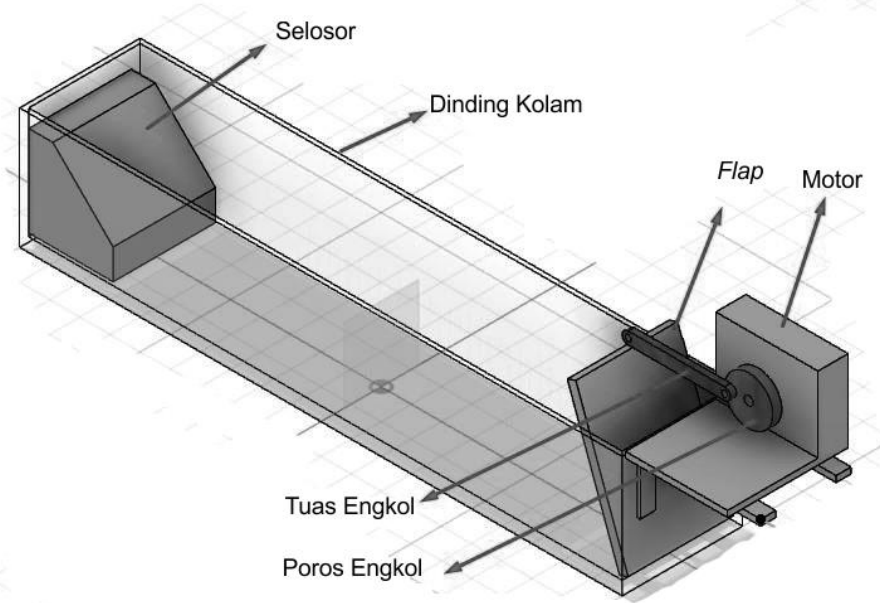

Gambar 2. Prototipe Tanki Pembangkit Gelombang. 
Mekanisme yang digunakan dalam pengukuran ialah model prototipe kolam menggunakan sistem engkol yang berkaitan dengan motor serta lengan ayun yang terkoneksi dengan plat pendorong sebagai pembangkit gelombang ditunjukkan pada Gambar 2. Dimensi kolam gelombang dengan panjang 2.5 meter, tinggi dinding 0.4 meter, dan lebar 0.4 meter.

Parameter yang diukur adalah aplitudo gelombang $(A)$ dan periode gelombang $(T)$. Dimana metode yang digunakan adalah pengamatan atau observasi pada dinding kolam dengan bantuan penggaris ukur, stopwatch dan kamera sebagai alat perekam gambar.

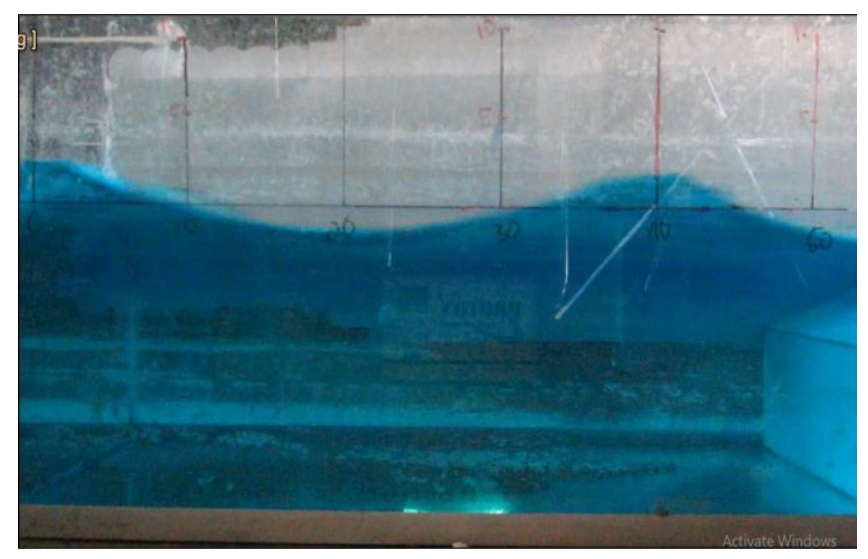

(a)

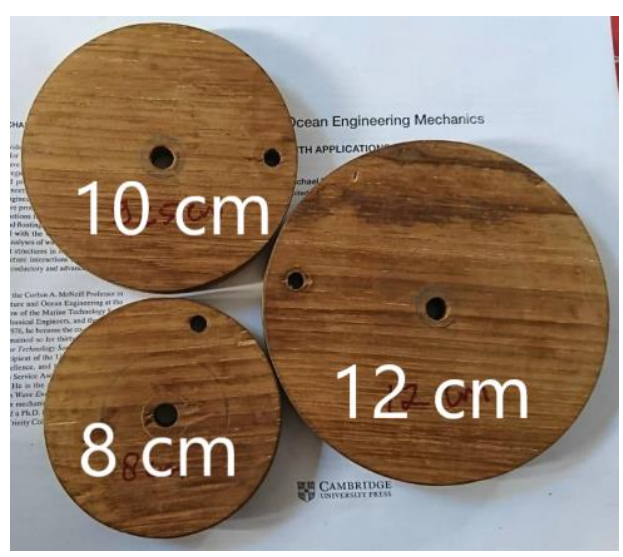

(b)

Gambar 3. a) Dinding Kolam, b) Disk Engkol

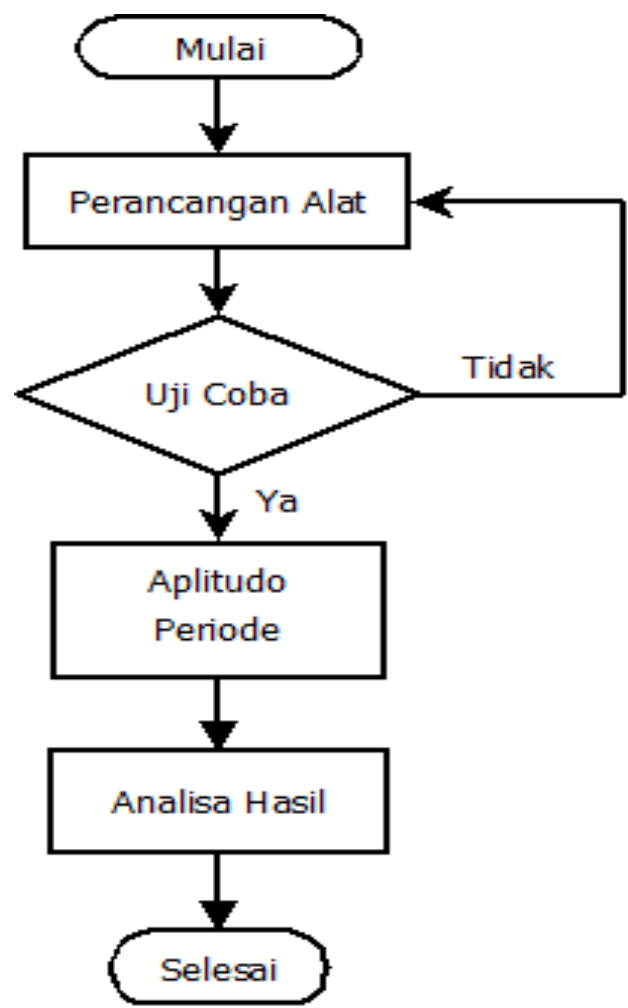

Gambar 3. Flowcart Percobaan. 
Alur percobaan adalah dengan merancang motor penggerak yang dapat diatur kecepatan putaranya, kemudian membuat variasi 3 disk seperti pada gambar no, $2 b$ dengan masing-masing besar diameter. Mekanisme pembangkit gelombang ini menggunakan material kayu, dimana kayu lebih muda dalam proses pembuatannya dan tidak mudah korosi. Untuk lengkapnya alur pengujian dapan dilihat pada gambar 3 dibawah ini.

Diagram alir diatas adalah alur percobaan dimana setelah mekanisme pada prototipe kolam pembangkit gelombang dibuat maka selanjutnya dilakukan pengujian dengan parameter yang diharapkan adalah, amplitude dan periode gelombang. Selanjutnya digunakan analisa untuk menentukan frekuensi dan daya yang dihasilkan oleh gelombang.

$E=\frac{1}{2}$

\section{HASIL DAN PEMBAHASAN}

Pada hasil percobaan menggunakan variasi diameter engkol 1,2,3 dengan perbandingan putaran pada poros engkol 1 dan 2 didapat hasil pada tabel 1 dibawah ini. Hasil pada tabel 1 adalah hasil pengukuran dari tinggi amplitude gelombang, dimana semakin besar diameter pada disk engkol maka semakin besar pula tinggi gelombang. Hal ini dikarenakan diameter engkol mempengaruhi langkah gerak pada kolom pembangkit gelombang, sedangkan dengan perbandingan putaran didapat putaran $120 \mathrm{rpm}$ atau kecepatan 2 yang lebih tinggi, ada hal yang menarik pada hasil ini, dimana pada perbandingan kecepatan dengan engkol 3 memiliki karakter yang sama dimana amplitudo gelombang memikili besar yang sama, hal ini dikarenakan pada pemakaian putaran keduanya tidak berpengaruh terhadap enkol nomor 3.

Tabel 1. Amplitudo Gelombang

\begin{tabular}{ccccc}
\hline Putaran Engkol (rpm) & \multicolumn{3}{c}{ Aplitudo Gelombang (mm) } \\
\cline { 3 - 5 } & & Disk Engkol 1 & Disk Engkol 2 & Disk Engkol 3 \\
\hline $\mathrm{V}_{1}$ & 100 & 20 & 20 & 30 \\
\hline $\mathrm{V}_{2}$ & 120 & 25 & 25 & 30 \\
\hline
\end{tabular}

Sedangkan pada pengamatan periode gelombang menggunakan rekaman video untuk mendapat waktu yang dibutuhkan dalam 1 gelombang didapat hasil dimana pada variasi diameter disk menunjukkan hasil yang lebih meningkat, artinya semakin besar disk maka semakin lama waktu yang dibutuhkan, sedangkan pada perbandingan putaran didapat bahwa kecepatan putaran engkol mempengaruhi waktu pembentukan gelombang, yaitu semakin tinggi putaran waktu yang dibutuhkan untuk mencapai 1 gelombang lebih sedikit dibandingkan dengan putaran yang lebih rendah.

Tabel 2. Periode Gelombang

\begin{tabular}{ccccc}
\hline \multirow{2}{*}{ Putaran Engkol (rpm) } & \multicolumn{3}{c}{ Periode Gelombang (s) } \\
\cline { 2 - 5 } & & Disk Engkol 1 & Disk Engkol 2 & Disk Engkol 3 \\
\hline $\mathrm{V}_{1}$ & 100 & 0.43 & 0.53 & 0.54 \\
\hline $\mathrm{V}_{2}$ & 120 & 0.35 & 0.43 & 0.5 \\
\hline
\end{tabular}


Pada Tabel 3 adalah hasil dari analisis frekuensi gelombang, dimana frekuensi adalah gelombang dibagi dengan periode gelombang, yang hasilnya berbanding terbalik dengan periode. Pada frekuensi didapat semakin besar disk engkol yang digunakan maka semakin kecil frekuensi yang dihasilkan. Hal ini dipengaruhi oleh pembentukan gelombang pada mekanisme ini tidak cukup efisien dalam menghasilkan gelombang tinggi, dikarenakan model pengolakan gelombang sangat dipengaruhi oleh masa jenis air.

Tabel 3. Frekuensi Gelombang

\begin{tabular}{ccccc}
\hline \multirow{2}{*}{ Putaran Engkol $(\mathrm{rpm})$} & \multicolumn{3}{c}{ Frekuensi Gelombang (Hz) } \\
\cline { 2 - 5 } & & Disk Engkol 1 & Disk Engkol 2 & Disk Engkol 3 \\
\hline $\mathrm{V}_{1}$ & 100 & 2.33 & 1.88 & 1.85 \\
\hline $\mathrm{V}_{2}$ & 120 & 2.83 & 2.33 & 2 \\
\hline
\end{tabular}

Hasil pada luaran penelitian yang terakhir adalah daya gelombang, seperti yang ditunjukkan pada Tabel 4 dan Gambar 4b. Pada hasil daya dengan variasi diameter disk ini memiliki kesinambungan terhadap hasil amplitude gelombang, dimana daya gelombang sangat dipengaruhi oleh amplitude, semakin besar amplitude gelombang atau tinggi gelombang maka semakin besar pula daya yang dihasilkan. Tentu hasil ini tidak dapat dijadikan sebagai acuan dalam menentukan besar energi yang didapat dalam aplikasi sebenarnya di lautan, karena selain tinggi gelombang panjang gelombang juga mempengaruhi.

Tabel 4. Daya Gelombang

\begin{tabular}{ccccc}
\hline \multirow{2}{*}{ Putaran Engkol (rpm) } & \multicolumn{3}{c}{ Daya Gelombang (J/s) } \\
\cline { 2 - 5 } & & Disk Engkol 1 & Disk Engkol 2 & Disk Engkol 3 \\
\hline $\mathrm{V}_{1}$ & 100 & 1.96 & 1.96 & 4.41 \\
\hline $\mathrm{V}_{2}$ & 120 & 3.06 & 3.06 & 4.41 \\
\hline
\end{tabular}

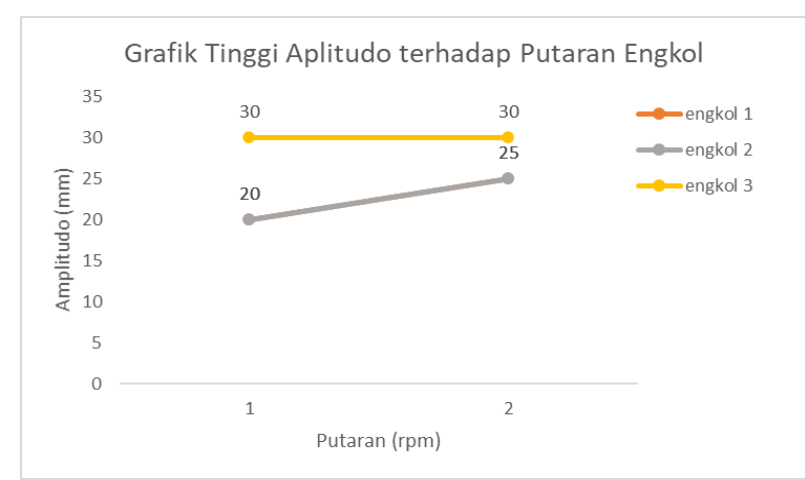

(a)

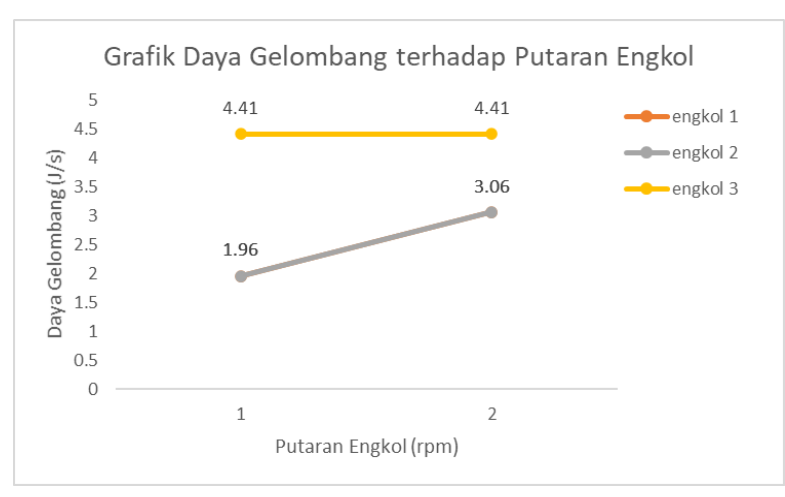

(b)

Gambar 4. a) Grafik Amplitudo terhadap Putaran, b) Grafik Daya terhadap Putaran

\section{KESIMPULAN}

Dari penelitian ini dapat disimpulkan bahwa dengan variasi diameter disk dan perbandingan putaran engkol pada mekanisme pembangkit gelombang model prototipe ayun ini memiliki hasil yang cukup signifikan. Dimana dengan diameter disk semakin besar maka semakin besar pula amplitude gelombang yang dihasilkan, sedangkan pada 
perbandingan putaran semakin tinggi putaran maka semakin cepat pula waktu yang dibutuhkan dalam pembentukan gelombang. Namun dalam model ini hasil yang terbaik lebih dominan pada diameter disk 3 dengan nilai diameter $12 \mathrm{~cm}$, sedangkan kecepatan engkol hanya sedikit mempengaruhi kenaikan jika menggunakan disk 3, perbandingan kecepatan lebih dominan terlihat pada disk 1 dan 2. Hal ini didapatkan hasil dimana pada disk 3 menjadi parameter maksimal pada mekanisme ini. Pada hasil frekuensi gelombang didapat hasil terbesar pada disk 1 dengan kecepatan 2 dimana pada mekanisme ini mendukung nilai frekuensi tinggi karena gerakan yang lebih ringan dan beban yang lebih kecil akibatnya gelombang lebih banyak terbentuk.

\section{DEKLARASI PENULIS}

Penulis menyatakan tidak ada potensi konflik kepentingan dengan sehubungan dengan penelitian, kepenulisan, dan / atau publikasi ini artikel.

\section{PENDANAAN}

Penulis tidak menerima dukungan finansial untuk penelitian, kepenulisan, dan/atau publikasi artikel ini.

\section{DAFTAR PUSTAKA}

[1] I Made Agus Dharma Susila dan Dwi Rahmasari Pribadi, "Analisis Konsumsi Listrik Dan Indeks Pembangunan Manusia (Ipm) Di Indonesia Analysis of Electricity Consumption and Human Development Index (Hdi) in Indonesia," Juni, vol. 13, no. 1, pp. 61-68, 2014.

[2] M. P. Kazmierkowski and M. Jasiński, "Power electronics for renewable sea wave energy," Proc. Int. Conf. Optim. Electr. Electron. Equipment, OPTIM, pp. 4-9, 2010, doi: 10.1109/OPTIM.2010.5510476.

[3] A. Noerpamoengkas and M. Ulum, "Pemodelan Pengaruh Frekuensi Dan Amplitudo Eksitasi Terhadap Respon Gerak Dan Daya Mekanis Pendulum Vertikal Pada Konverter Energi Gelombang Laut," Pros. Semin. Nas. Sains dan Teknol. Terap. III, pp. 201-210, 2015.

[4] M. Ulum, "Analysis on Electrical Energy from Cylindrical-Buoy-Type Sea Wave Power Plant Model," 7th Annu. Basic Sci. Int. Conf., pp. 1-4, 2017, [Online].

Available: http://basic.ub.ac.id/files/proceeding/PROCEEDINGS-BASIC-2017VOL3.pdf.

[5] Y. Pamungkas et al., "Study Eksperimental Pembangkit Listrik Tenaga Gelombang Laut Metode Mekanis Apung Menggunakan Sistem Transmisi Sproket dan Variasi Panjang Lengan."

[6] R. Alamian, R. Shafaghat, S. J. Miri, N. Yazdanshenas, and M. Shakeri, "Evaluation of technologies for harvesting wave energy in Caspian Sea," Renew. Sustain. Energy Rev., vol. 32, pp. 468-476, 2014, doi: 10.1016/j.rser.2014.01.036.

[7] R. Dicky Setiawan, T. Cimurti, R. Kurniawan, and D. Hermawan, "Pemanfaatan Gelombang Air Laut Untuk Pembangkit Tenaga Listrik Mini Berbasis Mikrohidro System," 2013. Accessed: Jan. 21, 2021. [Online]. Available: http://publishingwidyagama.ac.id/ejournalv2/index.php/proton/article/view/18 4.

[8] Michael E. McCormick, Ocean Engineering Mechanics. Cambridge, United States of America: Cambridge University Press, 2010. 